\title{
The Gospel and the Impact of Poverty on the Practice of Ideal Christianity in Nigeria
}

\author{
Adeyanju, James O. PhD \\ Lecturer, ECWA Theological Seminary, Igbaja, Kwara State, Nigeria
}

Babalola Emmanuel O.

Lecturer, Pan African College of Education Offa, Kwara State, Nigeria

\begin{abstract}
In Africa, poverty is one of the problems that have continued to reduce to little effects most of the struggle made to make life meaningful to the generality of the African people. As the various government continues to introduce various programmes to alleviate poverty, Christian Churches seem not doing enough in consolidating the various government efforts to solve the problem of poverty. Despite the numerical growth of Christianity in Nigeria, the adverse effect of poverty in the nation has undermined the significance of this numerical growth. The desperate attempt to solve the problem of poverty anyhow by an individual member of different Churches in Nigeria has called into question the true practice of Christianity. Some are using ungodly ways to solve the problem of poverty as a result of the fact that Christian Churches are not active enough in solving the problem of poverty. Since by its nature, the Church is founded to promote Jesus' ministry of providing both the physical and spiritual needs of people, the reality of poverty in the nation is making the major assignments of the Church of Christ which include the conversion of souls, showing mercy to the needy and other philanthropic services to the masses to be at stake. As the higher percentage of Nigeria populace are wallowing in abject poverty, this paper, therefore, sees it as imperative to examine the growth of Christianity in Nigeria and the negative impact of poverty on the practice of Christianity in Nigeria. Made also are the probable solutions that will help the Church to faithfully fulfill her mission as a true representative of Christ by providing both the spiritual and physical needs of the Nigerians. It is only through this that the Church can serve as a contriving source of encouragement to the government and the Nigerians in the struggle for the liberation of the poor, bridging the gap between the rich and the poor through various poverty alleviating programmes and heart changing messages that will help both poor and the rich to have right attitude towards wealth.
\end{abstract}

Keywords: Poverty, Gospel, Growth, Empowerment, Ideal

\section{INTRODUCTION}

There is a strong link between what happens in society and the way religion is practiced in any clime. In Nigeria, Christian religion through the proclamation of the Gospel has had its way; hence its present expansion incidence. From a handful of missionaries who planted the Christian faith in the country, the Church has expanded in so many ways - there are mission Churches, Africa indigenous Churches and yet there are many are privately owned by individuals. These scenarios suggest one fact: the Church is growing, recording an increasing number of adherents. The growing numerical rate is however undermined by poverty, which has severely bedeviled its qualitative stance. While so many worshippers gather in Cathedrals, Church Halls, Camps, Picnics, and Prayer-mountains today on designated days, those who sincerely throng such centresto obey God further are seriously dwindling. The level of poverty in the land - occasioned by corruption, lack of proper planning, natural disaster, ethnoreligious crises and terrorism, injustice among others, from which people want to escape has caused half-hearted religiosity in Church circles. The paper examines the beginning and growth of Christianity in Nigeria, the incidence of poverty and its attendant havoc on the practice of Christian religion in the land. It also suggests some ways out of the conundrum.

\section{NIGERIA'S CONTACT WITH CHRISTIANITY AND ITS GROWTH}

Nigeria is relatively a large country in the West Africa's sub-region comity of nations in the African continent; it occupies about approximately 924,000 square kilometres and lying between $4^{0} 161$ and $13^{0} 531$ North Latitude and between $2^{0} 40^{\prime}$ and $14^{0} 41^{\prime}$ East Longitude. It is bordered in the South by 
Adeyanju, James O. \& Babalola Emmanuel O. "The Gospel and the Impact of Poverty on the Practice of Ideal Christianity in Nigeria"

approximately 800 kilometres of the Atlantic Ocean, in the West by the Republic of Benin, in the North by the Republic of Niger and in the East by the Republic of Cameroon. Although its land mass is lower than those of Sudan, Algeria, Democratic Republic of Congo, Libya, Chad, Niger, Angola, Mali, South Africa and a few others in Africa, Nigeria prides itself as the most populous nation in Africa and, in fact, in the Black nation of the world for which reason it is often referred to as the "Giant of Africa." The 2006 National Population Commission (NPC) put the national population at about 140 million people. The NPC estimate indicated that the population has since risen to about 163 million in 2010. A further unconfirmed report (2014) puts the population at about 177.15 million, its growth rate at $2.4 \%$, birth rate at $38.03 / 1000$. The same report says its infant mortality rate is $74.09 / 1000$ while its life expectancy is rated at 52.62 years. The population, no doubt must continually increase; but it has three dominating ethnic groups - Hausa-Fulani, Yoruba, and Igbo (or Ibo). The Hausa-Fulani are located in the North, Yoruba in the West and the Igbo in the East. Under these three dominating tribes are found numerous others such as Urhobo, Itshekiri, Bini, Ekiti, Ijebu, Oyo, Ijaw, Idoma, Igala, Igbira, Kanuri, Gbagyi, Nok, Berom, Ogoni, and so on. Numbering between 250 and 300 .

In recent decades, religion has become an important factor in public debate and as a means of political mobilizations in many countries of the world. In Nigeria, the story is not different. In an African continent where at least 4,000 new professions of faith are made every day, and thus making it presently the most "Christian" continent in the world according to the projection of Bediako (2000) and O'Donovan (2000) the Gospel's proclamation has had its turn and Nigeria Christianity invariably has had its share of growth. The Gospel - whose proclamation centres on the historic intervention of God in human affairs through the event of Christ - is the vehicular medium necessary for the takingoff of the Christian Church in any clime. His post-resurrection last charge to his disciples, otherwise known as The Great Commission, connotes the fact that the Church would be planted in many lands and cultures beyond the enclave of ancient Judea where the charge was initially issued.

Incidentally, the beginning and development of Christian religion in Nigeria can be divided into five periods: (i) the period of Latin Christianity in the $15^{\text {th }}$ and $16^{\text {th }}$ centuries; (ii) the term of Denominationalism and missionary activities in the $19^{\text {th }}$ century from 1842 onward; (iii) the term of evolution of independent Churches; (iv) the period of indigenous African Churches; and (v) the period of the birth of the Charismatic and Pentecostal Churches. This periodic analysis is done by Adamolekun (2016) in his Main Trends in the Church Growth in Nigeria although his third and fourth divisions can be grouped together. The start offevent is traceable to the period of the Portuguese voyage of the $15^{\text {th }}$ century (c. 1472) through which the Roman Catholic Portuguese struggled to plant Christianity in Benin and Warri respectively although the venture did not last because of slave trade aberration that accompanied it (Adamo and Enuwosa, 2004). At this period, the Western missionaries employed the mode of planting the Christian faith through Church-State relationship by targeting the kings for conversion, with churches built around the palaces of converted kings (Hodgkin, 1975). Even a missionary follow-up undertaking of 200 years later did not yield much fruit. At about 1800 some Roman Catholic missionaries planted successful and vibrant Churches along the South-eastern axis of the country although their success was limited to the Igbo and other related tribes at the time. A missionary effort that had much wider effect was occasioned by the arrival of Protestant missionaries - the Wesleyan Methodists - who had to work among freed slaves in Nigeria via Sierra Leone to Badagry in Lagos in 1842 and were tutored by the Church Missionary Society (CMS). This dates back to the abolition of the Trans-Atlantic slave trade in the early $18^{\text {th }}$ century, which was followed by the emergence of a literate African elite, consisting of liberated and returned slaves as well as local converts in coastal cities such as Lagos, Abeokuta and Badagry (Danjibo, 2016).

From this period, and due to the impact of the vibrant activities of the missionaries, Christianity started to be and has, in fact, become a major religion to reckon with in Nigeria till date. This is part of what Bediako (2000) called the "Surprise Story" of modern missions - the emergence of "Christian Africa. The impactful enterprise was not however done by one or a few of missionaries; it was a religious business coordinated by various foreign missions that arrived the country at different times. Early missions included the Wesleyan Methodists (1842), Scottish Presbyterian (1842), Church Missionary Society (1844), Southern Baptist Foreign Mission (1850), Roman Catholic Mission (1861), Sudan Interior Mission (1893), Sudan United Mission (1904), United Missionary Society (1905), Seventh Day Adventists (1914), Qua Iboe Mission (1932), Assemblies of God (1939), and African Church Movements (1888-1925). 
Adeyanju, James O. \& Babalola Emmanuel O. "The Gospel and the Impact of Poverty on the Practice of Ideal Christianity in Nigeria"

An unverified Report, relying on the fact that there is a high number of missionaries in the country, claims that the percentage of Christians in Nigeria grew from 21.4\% in 1953 to 48.2 in 2003. Today, Nigeria is one of the leading nations in the African continent with the highest Christian presence and witness in terms of population. By 1970s there were more than 50 Mission Agencies operating in the country as a result of which Christianity has grown and become one of the dominant religions (cf. Islam and Africa Traditional Religion) in the nation. In their joint work, Turaki and Galadima (2001) assert that over $45 \%$ of the population of Nigeria embraces Christianity (Galadima, 2001). The agencies of education, medical services, crafts centres, and literature ministry employed by the Church have provided invaluable assistance to ascertain the possibility of this significant feat. It is noteworthy that elitism fueled by western formal education in the country first developed along the founding and growth of the Christian religion. Consequently, Christianity became a fountain for western formal education to flourish in Nigeria up to date.

It is alarming that every major city and town in Nigeria is littered with one Church denomination or the other as well as different mosques. Africans were already religious before their conversion to either Christianity or Islam through their adherence to traditional religious practices and customs (Emmanuel, 2014). They are attracted to the Christian faith because they wish to retain their religious heritage and at the same time seek refuge through the power of Christ that can surely protect them from different spiritual (or metaphysical) hazards of this world. These are oftenbelieved to be caused by invisible diabolical spiritual beings the Yoruba designate as Omo Araye and from other climatic and ecological problems to which they have little or no explanation (Odejobi, 2004).

The on-going propagation of the Christian religion cannot be undermined; it has given rise to mainline denominations coupled with the indigenous ones, established by native Africans. These include the Methodist Church, Nigeria, Church of Nigeria Anglican Communion, Catholic Church, Presbyterian Church, Baptist Churches (Nigerian Baptist Convention and other Independent Baptists), Evangelical Church Winning All (ECWA), Church of Christ In Nations (COCIN), The Apostolic Church, Assemblies of God, Qua Iboe Church, etc. The independent Churches also include Christ Apostolic Church (CAC), Cherubim and Seraphim Church, Celestial Church of Christ (CCC), Church of the Lord (Aladura) among others (Oshitelu, 2007). Later, with the incursion of Pentecostalism in the country, there was the evolution of Redeemed Christian Church of God, Deeper Life Bible Church, Foursquare Gospel Church, Gospel Faith International, and so on. These are apart from those considered as Christian sects such as Seventh Day Adventists, Jehovah's Witnesses, Christian Scientists, and Church of Jesus Christ of Latter-Day Saints among others.

Presently, there are neo-Pentecostal Church denominations Living Faith Church (a.k.a. Winner Chapel), Mountain of Fire and Miracles (MFM), Christ Embassy, Synagogue Church of All Nations (SCOAN), and several others. The list is endless. However, most of the Churches in this category are privately owned by an individual or group of people. It also worth noting that one of the Christian agencies, Scripture Union (SU) played a major role in the expansion of Christianity in the nation. Most of these Church denominations are located in the North-central and Southern part of the country. By its nature, the Church is founded to promote Jesus' mission in the world; therefore, its principal assignments which condition its practice to include conversion of souls, instructional activities especially directed to the members as well as ministering mercy to the suffering world through good works. These programmesare usually achieved through biblical teaching and preaching, counseling, prayers, and philanthropic services, and others. These denominations might seem to be heterogeneous in outlook - some with uniform, some Western in nature, some African in their approach; all are gathered under the political flagship of Christian Association of Nigeria (CAN) formally founded in 1982. Nevertheless, two important issues are common to all among others. These are (i) the Holy Scriptures; and (ii) the person as well as the historic event of Christ; any religious group claiming Christian name is not worth it if these two major factors are found wanting (Somorin, 2002). Thus, up to the late 1980s, as deducible from Rowland Olumati's work, the Church remained committed to the laudable tasks given it by Jesus Christ. Not minding some internal squabbles (e.g. division and unhealthy leadership ambition), the Church gave itself to evangelical activities, edification of members through thorough Bible Study and prayers (Rowland, 2015). According to Kitause and Achunike (2013) who assert: 
Adeyanju, James O. \& Babalola Emmanuel O. "The Gospel and the Impact of Poverty on the Practice of Ideal Christianity in Nigeria"

There is so much religiosity in Nigeria in the $21^{\text {st }}$ century.There seem to be so much church activities, conferences, conventions, retreats, crusades, pilgrimages, night vigils, picnics, evangelistic campaigns, without many corresponding spiritualities and moral growth...Cases of immorality..., armed robbery...kidnapping, examination malpractice...,corruption and the like abound...with Christians and Muslims topping the lists as culprits (p.46).

As noticeable from the 1990s to date, the Church, being a segment of the Nigerian society, has been greatly influenced by poverty heightened by ethnoreligious wars and has started to jettison its true allegiance to Jesus Christ and the moral element of his religion. With this, one could concur with them that many Nigerians are religious without being righteous. All the prayer and fasting and attendance of services do not reflect the true teachings of the major religions. Adherents of the religions appear to have compartmentalized their lives such that what is taught in Churches or Mosques stay only there and do not transform to reality after that (Imosem, 2012).

\section{THE PRESENT SCENARIO OF POVERTY IN NIGERIA}

Poverty as a socio-economic issue, cannot be pinned down to a particular definition; its wide range of meanings has been precipitated by scholarly perception from different disciplinary approaches and ideologies. Since World War II, a Western definition of poverty has been based on monetary terms, employing levels of income or consumption to measure poverty and defining the poor by a headcount of those who fall below a given income/consumption level or "poverty line." The definition has nevertheless been complemented by other various approaches which view poverty situation in a more multidimensional way, including the basic needs approach, the capabilities approach, and the human development approach. These approaches have apparently gained acceptance and they are widespread in the way United Nations Development Programme (UNDP)'s Human Development Index (HDI) incorporated them into its view of poverty which takes into consideration three dimensions of human development: (i) Life expectancy; (ii) educational attainment; and (iii) standard of living, measured by income in terms of its purchasing power parity (UNDP, 2006).

Invariably then, poverty can be simply defined as "lack of opportunity to develop human abilities and to control own human lives because of economic or material deprivation (Kunyihop, 2001). This basic definition connotes material lack or wants, deprivation in human capacity development, lack of access to resources, insecurity among others. From practical experience, wherever poverty exercises its sway, undue resource control, physical weakness (as in the cases of malnutrition, disability, etc.), isolation (marginalization, discrimination, etc.), vulnerability (to contingencies which increase poverty e.g. war, climatic changes, etc.), powerlessness (the inability to avoid poverty itself or to modify the situation), etc. are not found wanting.These harsh situations do occur when people cannot access income and other resources needed to attain proper conditions of life such as good diet, material goods, amenities, standards and services which, in turn, enable them to play the roles, meet the obligations and participate in the family relationships and customs of their society.

While it is noteworthy to mention that some people are poor for lack of proper planning in national, group, family or personal levels, some wallow in penury because of reasons beyond their control such as natural ecological, climatic or environmental factors (e.g. drought, flood, tsunami, earthquake, and so on. Others are poor because of ethnoreligious wars, terrorism, and the likes. In Nigeria, poverty "successfully" thrives for faulty or lack of national socio-economic planning. The below table from Nigeria Poverty Profile 2010as shown by National Bureau Statistics showcasing the percentage of Nigeria poverty situation from 1980 to 2010 is amazing because of its ever-increasing state despite the actualization of the New Millennium Development's goals:

\begin{tabular}{|l|l|l|l|}
\hline Year & Poverty Incidence \% & Estimated Population (Million) & Population in poverty (Million) \\
\hline 1980 & 27.2 & 65 & 17.1 \\
\hline 1985 & 46.3 & 75 & 34.7 \\
\hline 1992 & 42.7 & 91.5 & 39.2 \\
\hline 1996 & 65.6 & 102.3 & 67.1 \\
\hline 2004 & 54.4 & 126.3 & 68.7 \\
\hline 2010 & 69.0 & 163 & 112.5 \\
\hline
\end{tabular}

Source: National Bureau of Statistics (Harmonized Nigeria Living Standard Survey), 2010. 
Adeyanju, James O. \& Babalola Emmanuel O. "The Gospel and the Impact of Poverty on the Practice of Ideal Christianity in Nigeria"

It is crystal clear that the derivable wealth from over 50 years of oil exploration, pathetically pursued in exchange for agricultural economics before the Oil Boom, in the country has not been managed properly for the common good. This is because as Solomon Ademiluka (2011) rightly points out, "Just as the $8^{\text {th }}$ century ushered in a period of unprecedented wealth in Israel, the discovery of oil in the Niger Delta placed Nigeria among the richest nations of the world." However, just as the wealth was monopolized by the upper class in Israel, Nigeria has been stratified into upper and lower classes with the upper class controlling the resources and forcing other into destitution. Hence its attendant corrupt practices were inevitable because most politicians and their cronies who view the Oil Money as a National Cake stash the Commonwealth of the country in their foreign bank accounts in Europe and America. Its attendant curse was joblessness. Unemployment alone has contributed in no small way to aggravate the scene of religious crises and tribal uproars in Nigeria; members of ethnoreligious crises in the country have been teeming unemployed youth, an incident which provides ready soldiers for such wars, and has plunged Nigeria into a bedlam of problems and challenges which have dire consequences for the country (Odeh, 2012). Other issues like the fuel crisis, Fulani herdsmen crisis, water crisis and even food crisis are also crying for attention. Although no society can be totally free from poverty, the analytical table above indicates that the rate of poverty increased and the population of people it engulfs increases to $69 \%$ of the entire population as at 2010. All the measures put into place to stem the tide of poverty such as 1979 Green Revolution Programme (GRP), 1986 Directorate of Food, Roads, and Rural Infrastructure (DFRRI), 1993 Family Support Programme (FSP) and Family Economic Advancement Programme (FEAP), 2001 National Poverty Eradication Programme (NAPEP) which were follow-up to 1972 National Accelerated Food Production Programme (NAFPP) and Nigerian Agricultural and Cooperative Bank, 1976 Operation Feed the Nation (OFN), have achieved only a little result. For example, according to the above National Bureau of Statistics (2007), Nigeria's poverty level in 1996 was $65.5 \%$, and the poverty population was 67.1 million. The report indicates among others the magnitude of pain and agony into which majority of the Nigerians have been immersed since then. Another Report made available by National Bureau of Statistics of poverty headcount figures for 2010 and forecast/estimate for 2011 indicates that the "incidence of poverty in Nigeria worsened between 2004 and 2010." The Report shows that the number of Nigerians living below the poverty line rose from 68.7 million to 112.5 million (i.e. $63.7 \%$ rise in poverty incidence) during the period while the population rose from 139.2 million to 158.6 million (13.9\% rise in population) between 2004 and 2010. Eventually,during that period (i.e. 2004 - 2010), the Nigerian economy was growing strongly at an average annual growth rate more than $6.6 \%$, making the country the fifth fastest growing economy in the World in 2010 at $7.87 \%$ real growth rate. The paradox of growth in the face of poverty and inequality and injustice in Nigeria's socio-politico-economic distribution, with $1 \%$ of the population (politicians and bureaucrats) allocating the resources of the country to themselves while the rest of the populace wallow in abject poverty (Ogbonaiya, 2012). Nwagwu (2014) equally agrees with the submission above and attributes the persistence of poverty in Nigeria to income inequality, long-term ethnoreligious conflicts, civil unrests and political instability. His assertion on income inequality is quite accurate especially when viewed from the fact that Nigeria's Members of Parliament (MPs) earn more than their counterparts all over the world. Only $31 \%$ percent of Nigerian populace lived above the poverty line in 2010. This is somewhat pathetic in a country (Nigeria) with a nominal GDP of $\$ 207.11 \mathrm{bn}$ and per capital income of $\$ 1,401$ and which claims to be the second largest economy in Africa as at 2011 (Ayedogbon and Ohwosafa, 2012).

Presently, poverty in Nigeria is complicated by the lack of provision of social amenities - stable electricity, good roads, potable water, health facilities, and so on. To make matter worse, the everrising cases of militancy, kidnapping and terrorism do not help matters in this context. Coupled with this is present conundrum of the shortfall in global Crude Oil Price whereby Federal Allocations to the federating states in the country have also drastically reduced to the point where most States and Local Governments cannot afford to pay their workers' monthly salaries As at the inauguration of President Muhammadu Buhari's government on May 29, 2015, 27 States of Nigeria are said to be deficient of enough fund to pay their workers monthly wages. Almost a year after, 24 States still cannot pay salaries despite the bailout fund dished out to them through the initiative of the Federal Government (Usigbe, 2016). This study quite agrees with Augustine U. Nebechukwu who avers that poverty is not the result of chance, destiny or fate. In Nebechukwu's assertion, it is even less the will of God. It is rather the bad will of men and women rooted in social, political, religious, economic and cultural injustice (Nebechukwu, 1990). In its Joint Report on Social Inclusion (2004), the European Commission came up with the following statements on poverty: 
Adeyanju, James O. \& Babalola Emmanuel O. "The Gospel and the Impact of Poverty on the Practice of Ideal Christianity in Nigeria"

People are said to be living in poverty if their income and resources are so inadequate as to preclude them from having a standard of living considered acceptable in the society in which they live. Because of their poverty, they may experience multiple disadvantages through unemployment, low income, poor housing, and inadequate health care barriers to lifelong learning, culture, sport, and recreation. They are often excluded and marginalized from participating in activities (economic, social and cultural) that are the norm for other people and their access to fundamental rights may be restricted.

The complicated scenario has occasioned infant mortality, low standard of education, reduction in human lifespan, increase in crimes such robbery, kidnapping, and even terrorism. E. J. Nwagwu (2014) says, "The majority of Nigeria population, the poor people in affluent society, is enmeshed in the net of poverty." As he rightly affirms, "The Nigerian government seems to have failed in its contractual obligation to respect and sustain its social contract with the people'. As a result of the seemingly total collapse of social security, some elements have taken to alternative means prostitution, brain drain, cheating, and other fraudulent practices - to earn a living, incidents which have socio-economic, political and moral consequences on how religion is practiced in the country. George and Amusan (2016) teach the importance of religion in the national development programme of any nation in the following statements:

...It has been acknowledged as one of the bedrocks of socio-economic and political advancement of many countries in the world. Religion exemplifies morals and advocates uprightness and piety, as opposed to sacrilege and profanity. Religion is...one of the most powerful social institutions in the social system that is used as an instrument of social cohesion, unity, and integration (p.310).

It is, however, unfortunate that poverty is more or less a big barrier, barricading the path of religion in its promotion of morality and ethical development of citizens of human capital in Nigeria. It has led to pretense among worshippers; many throng into religious centres for immediate material benefits to ameliorate their impoverished situations.

\section{THE NEGATIVE IMPACT OF POVERTY ON RELIGIOUS PRACTICE IN NIGERIA}

The situation, described above, has affected many things in the practice of religion particularly Christianity where the very tenet of the gospel has been thrown into the mud. In the first place, most Gospel Centres are flooded with people, who do not necessarily come for Christian instruction and enlightenment but rather make themselves available to seek a solution to their socio-economic problems. Many religious posters of Christian programmes have themes that read thus: "Accessing the Path to Success," "Encountering Jesus, the Richest," "The Road to Self-Sufficiency," "Breaking the Curse of Poverty," "Anointing for Financial Explosion" as pasted on every available conspicuous places by the roadsides of many Nigerian cities etc. without any significant consideration for the affiliation of the inquirers to God. The Church is by and large becoming worldlier, compromising its "saltiness" and enlightenment agency with the world. People hardly frequent in churches today for Bible Study because they think it will not bring any material benefit. It is possible and unknown to Church leaders today that looters of Nigerian treasury, armed robbers and even kidnappers pay tithes and donate to capital projects in the church because Jesus is now offered for sale as little or no emphasis is placed on conversion from sinful practices. Besides, not minding their situation of nudity in which they appear to the sanctuaries, the harsh economic condition have become nursery beds for false prophets and spiritualists who, while capitalizing on the harsh economic situation of the country, are milking unwary enquirers dry - they (false prophets and spiritualists) build mansions and ride the best and latest cars with little or no educational background (Adamolekun, 2016). This situation has successfully cropped up into the presence of Committees, Societies, and Clubs but without the presence of spiritual heat in the Church. Revival meetings are constantly held; evangelists and paid singers are brought to induce great attendance to (or "intending to")realizing higher financial collections. The irony of the matter is that unfortunately despite big financial collection there is little or no welfare package to ameliorate the pathetic situation of their poverty-stricken members. Only a few Church-denominations observe and execute this adequately.

Secondly, many young and middle-aged graduates who are jobless but quickly locate their place in the Church as they claim that they are called by God sooner than later after some failed efforts to secure jobs. As Tim Cantrell (2016) points out, the gospel advances are not tidy, and they take place 
Adeyanju, James O. \& Babalola Emmanuel O. "The Gospel and the Impact of Poverty on the Practice of Ideal Christianity in Nigeria"

through feeble, imperfect human instruments and often under perverse condition. This nascent set of "Pastors, Bishops, and Prophets" most of whom undermine religious or theological education not only bastardize Christian liturgy but have also succeeded in undermining the fundamental teachings of the Christian Church through their erroneous canon of biblical exegesis where most sacred texts are not just superstitious and syncretistic but are also twisted to "fight" enemies/perceived enemies and to raise "overnight millionaires" not minding the sincerity of the confessions of their worshippers. Dominic Umoh (2013) brilliantly argues that the modern Christian exegesis tainted by superstition and syncretism constitute setbacks to authentic Christian practice in Africa. In this $21^{\text {st }}$ century Nigeria, one can easily become a General Overseer (GO) or General Superintendent (GS), and so on with a little knowledge of philosophy, oration, confidence to face the crowd, and a Study Bible. That is not to conclude that there are no genuine and sincere GOs and GSs all over the country; the fruit of their ministerial career distinguish them out from the "crowds." However, somewhat akin to the event in the Temple in Jesus' time, most Churches have more or less becomes business centres: sales of Anointing Oil, Miracle Handkerchief, Miracle Money, Miracle Orange, Miracle Apple, Miracle Honey, Miracle Water, Miracle Wine and others. Special prayers are offered for few individuals who could dole out tangible amounts of money.

\section{CONCLUSION}

The biblical prayer, "Give me neither poverty nor riches - feed me with the food allotted to me; lest I be full and deny You, and say, 'Who is the LORD?' or lest I be poor and steal, and profane the name of my God," credited to Agur, son of Jakeh (Prov.30:8b-9, NKJV) is not without an important significance. Poverty could occasion immoral behaviour and attitude such as stealing, cheating, and other unwholesome practices in religion. Citing Dr. Christopher Kolade, Honourable High Commissioner to the United Kingdom (The UK, 2002), Somorin says, "Decadence, 'a process of decay,' is known to inflict deep injuries on the system of ethics of society before people's consciousness about it." The resulting effect, according to Kolade, is in the fact that "succeeding generations acquiesce in values and standards that are lower than the previous one, especially if they did not experience such values and standards at first hand.

The present spate of ethnoreligious conflicts in different parts of the country - in which tribes and religions search for ways to dominate the other politically or otherwise - is illustrative of the thesis of this paper. The underlying factor behind all the crises can be traced to nothing but monetary gain, recognition, and popularity. The religious dictates of each person who claims to be adherent to faith or the other are no longer considered being normative; religious preaching and teachings are considered unimportant unlike before. If the current tide of the economic hardship confronting religious people including Christians are facing in Nigeria is not stemmed, true religious teaching and modeling capacity of the Church through sound character and morality might be marred. The present moral condition of the country coupled with political chaos in the nation where almost half of the population are said to be Christians suggests that the situation has started to erode the significance of Christian religion unless the Churchdenominations are better established in the faith. Even political office holders including Christians - governors, members of parliament at all levels, ministers, advisers, special advisers, local government chairpersons, inspector general of police, directors and parastatals of government's establishments, judges and justices, etc. - who indulge in fraudulent practices do so with a view to evade poverty and thus to amass enough wealth for their posterity.

This article strongly pleads with government at all levels in Nigeria to put into place sound economic planning that will adequately take into consideration the interest of the populace. The Nigerian Church should as a matter of urgency revert to an atmosphere of love and unity where the basic needs of believers are taken care of by everyone especially the wealthy group in its ranks. Doing this will make the present day Church tow the path of the primitive Church (Acts 2:42-47; 4:32-34; 6:1ff). There can be trust funds in each parish or region of each denomination; and the trust fund must be accessible to the poor such as orphans, widows, the aged without children, those stricken with HIV/AIDs, ethnoreligious violence, wars, and terrorism.

Christian Churches should place high premium more than before on ethical values such as honesty, fair play, commitments, accountability and other virtues that are essential for sustenance of a good economic. The Church leaders should be vocal to declare what God has to say about greediness, bribery and corruption and other social vices that are jeopardizing Nigeria economic. There should be some prophetic voices like Isaiah and Amos to jerk up those who are in government to effectively control the resources of the land and influence them to formulate policies that will inaugurate 
Adeyanju, James O. \& Babalola Emmanuel O. "The Gospel and the Impact of Poverty on the Practice of Ideal Christianity in Nigeria"

reformation and change that Nigeria government is clamouring for. The Church leaders should also encourage Christians whom God has blessed abundantly to provide money and materials to those who have little.

The Church should use the principle of empowerment whereby people on an individual level can learn a job to skill to earn a living through projects of individual micro-industry. This will help the needy to become self-sustaining and even be able to help others. The Church should also educate Nigerian families to consider their physical, psychological and financial capabilities in deciding the number of children needed in each family.This will help the parents to raise a good home.

Christians should also develop themselves socio-economically and inculcate the spirit of creativity. They should not see white collar job as a priority. Instead, they should be ready to engage insmallscale enterprises and equip themselves vocationally. Laziness must be discouraged, bearing in mind that each person is responsible for (or her) welfare and that opportunity and fortune usually befriend the bold. Nigerians also should stop selling their votes to the politicians who indulge in presenting dishonest gifts rather than fulfilling their promises during the campaigns. As Jesus paid his tax for the development of His country, individuals, and non-governmental organizations should endeavour to pay their taxes and other revenues to the government for the development of the nation

\section{REFERENCES}

Adamo, D. T. and Enuwosa, J. "Missionaries Go Home: The Integrity of Mission in Africa," Paper for the IAMS Assembly in Malaysia (2004), 1-15, Retrieved from www.missionstudies.org Accessed on March 31, 2016.

Adamolekun, Taye. "Main Trends in the Church Growth in Nigeria," European Scientific Journal . October Edition Vol.8 No.27, pps.1-12. Retrieved from www.eujournal.org Accessed May 08, 2016.

Ademiluka, Solomon O. "Interpreting the Eighth Century Prophets in Israel in the Context of the Unrest in the Niger Delta Region of Nigeria," Massiwa Ragies Gunda (ed.), Bible in Africa Studies (BiAS): From Text to Practice, The Role of the Bible in Daily Living of African People Today Vol.4. University of Bamberg Press, 2011. Retrieved from BiAS4neuopusopt2e.pdf. Accessed May 6, 2016.

Ayedogbon, J. O. and Ohwofasa, B. O. "Poverty and Youth Unemployment in Nigeria, 1987- 2011," International Journal of Business and Social Science. Vol.3. No.20 (Special Issue October 2012.

Bediako, Kwame. Jesus in Africa. Accra: Regnum Africa, 2000.

Cantrell, Tim. "A Plea for Church-Strengthening Movements in Africa." Retrieved from www.sats. edu.za Accessed on April 9, 2016.

Galadima, Bulus Y. and Turaki, Yusufu. "Christianity in Nigeria," African Journal of Evangelical Theology (AJET) 20.1 (2001).

George, T. O. ,and Amusan, T. A. "Religion and Acts of Worship amongst the Nigerian People: Implications for Development and National Unity" in A. S. Jegede et al. (eds.), Peoples and Cultures of Nigeria, 310-326. Retrieved from www.eprints.covenantuniversity.edu.ng. Accessed March 28, 2016.

Hale, Thomas. The Applied New Testament Commentary. Colorado Springs: David C. Cook 2007.

Hodgkin, T. Nigerian Perspective $2^{\text {nd }}$ Ed. London: Oxford University Press, 1975.

Insa Nolte Centre for West African Studies, the University of Birmingham with Nathaniel Danjibo and Abubakar Oladeji, Nigerian Institute for Social and Economic Research, Ibadan, Religion, Politics, and Governance in Nigeria. Religion and Development Working Paper 39. International Development Department, p.6. Retrieved from www.birmingham.ac.uk. Accessed on April 26, 2016.

Isichei, Elizabeth. History of Christianity in Africa from Antiquity to the Present. London:SPCK.

Keener,Craig S. The IVP Bible Background Commentary: New Testament. Leicester: IVP, 1993.

Kitause, Rimamsikwe Habila and Achunike, Hilary Chukwuka. "Religion in Nigeria from 19002013," Research on Humanities and Social Sciences Vol.3. No. 18 (2013), pps. 45-56. Retrieved from www.iiste.org. Accessed May 14, 2016. 
Adeyanju, James O. \& Babalola Emmanuel O. "The Gospel and the Impact of Poverty on the Practice of Ideal Christianity in Nigeria"

Kunhiyop, Samuel W. "Poverty: Good News for Africa," African Journal of Evangelical Theology 20.1 (2001).

Mohammed, T. A. et al., "Ethno-Religious Conflicts in Nigeria: Revisited," Journal of Applied Sciences Research Vol.8. No.4 (2012).

Nebechukwu, Augustine U. "Solidarity with the Poor: Christian Response to Poverty," African Theological Journal 19.2 (1990).

Ngewa, Samuel. "John," Tokunboh Adeyemo et al. (eds.), Africa Bible Commentary. Grand Rapids: Zondervan Publishing House, 2006.

Nigeria Handbook: All You Want to Know about Nigeria. A Publication of Federal Ministry of Information, Abuja, Nigeria. Emmanuel Igah, Project Consultant, and Manager, 2014.

"Nigeria," http://www.infoplease.com/country/nigeria.html. Accessed April 25, 2016.

"Nigeria Poverty Profile 2010," Retrieved from www.nigerianstat.gov.ng. Accessed on March 28, 2016, 3 of 31.

Nwagwu, Ejikeme Jombo. "Unemployment and Poverty in Nigeria: A Link to National Insecurity," Global Journal of Politics and Law Research, Published by European Centre for Research Training and Development UK (www.ea-journals.org) Vol.2 No.1 (March 2014).

O’Donovan, Wilbur. Biblical Christianity in Modern Africa. Carlisle: Paternoster Press, 2000.

Odeh, L. E. "Historical Analysis of Ethno-Religious Violence in Nigeria," R. A. Raji (ed.), The Relevance of Religion in Contemporary Society, 2012, 47-62. Retrieved from Unilorin.edu.ng/publication/lemuel/odeh. Accessed May 6, 2016

Odejobi, C. O. "Influence of Yoruba Culture in Christian Religious Worship," International Journal of Social Science and Education. Vol.4, Issue 3 (2004).

Olumati, Rowland. "The Impact of Christianity and Modernity on Ali - Earth Goddess of the Traditional Religion in Ikwerre People, Rivers State, Nigeria," African Research Review: An International Multidisciplinary Journal, Ethiopia Vol.9. No.1 Serial No.36 (January 2015).

Oshitelu, G. A. History of the Aladura (Independent) Churches 1918-1940:An Interpretation Ibadan: Hope Publications, 2007.

Richards, Lawrence O. Bible Reader's Companion. Colorado Spring: Cook Communications, 2002.

Somorin, Kunle (ed.), Meditation and Reflection Fellowship: The Role of a Christian Citizen in a Corrupt Society. Dialogue 1 Saturday, $23^{\text {rd }}$ March 2002,7. Retrieved from www.africaleadership. org. May 6, 2016.

Umoh, D. "Superstition and Syncretism: Setbacks to Authentic Christian Practice in Africa," International Journal of Humanities and Social Science Invention Vol.2 Issue 7 (July 2013).

Usigbe, Leon. "Buhari to release more fund to states: President can't sleep with states in trouble," Nigerian Tribune (Friday 29 April 2016).

"What is meant by poverty?" Retrieved from www.jrf.org.uk/sites/default/files/jrf/migrated/files/ poverty-definitions.pdf. Accessed on March 22, 2016.

\section{AUTHOR'S BIOGRAPHY}

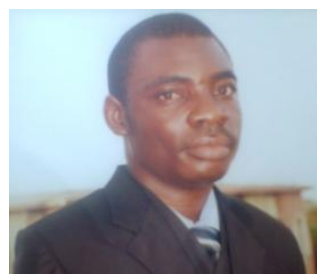

Babalola, Emmanuel O., was born on 12th April, 1974 in a town named Ayede Ekiti in Ekiti State of Nigeria. He obtained his first degree in Bible and Theology at ECWA Theological Seminary Igbaja, Kwara State of Nigeria in 2009. He later went to Usmanu Dan Fodiyo University Sokoto of Nigeria where he obtained his Post Graduate Diploma in Education (PGDE) in 2011. Obtained also is his master's in Christian Religious Studies at Olabisi Onabanjo University, Ago- Iwoye in Ogun State of Nigeria in 2013. He is currently a PhD candidate in the same university where he obtained his master's degree. The author also has to his credit published Journals and has attended various conferences and seminars. He is a member of Nigeria Association of Biblical Studies (NABIS) and National Association of Christian Religious Educators in Nigeria (NACREN). The author is a lecturer at Pan African College of Education in Offa, Kwara State and also an adjunct lecturer at ECWA Theological Seminary Igbaja, Kwara State. He is married to Mrs Victoria Babalola with three children. 